\title{
RELIGIOUS FRONTIERS IN THE SYRIAN-MESOPOTAMIAN DESERT
}

\section{LUCINDA DiRVEN}

Ever since Michael Rostovtzeff's article "Dura and the Problem of Parthian Art" was published in 1935, it has been common place to speak of cities in the Syrian-Mesopotamian desert, such as Palmyra, Hatra, DuraEuropos and Edessa, as belonging to the same cultural orbit. ${ }^{1}$ Whereas Rostovtzeff primarily argued for the existence of a shared material culture, others have put forward the concept of a shared language and religion. Han Drijvers, my much admired and sorely missed teacher, devoted many publications to the common cultural pattern in the cities of the Syrian Mesopotamian desert. Drijvers' highly influential article on Hatra, Palmyra and Edessa, published in Aufstieg und Niedergang der römischen Welt in 1977, linked these cities in the minds of many. ${ }^{2}$ Although historians such as Ted Kaizer have recently put some stress on the local characteristics of cities in Syria and Mesopotamia, ${ }^{3}$ the idea of a shared indigenous culture still dominates academic discourse. Michael Sommer's recent publication on Rome's eastern frontier zone is a case in point. ${ }^{4}$

If the notion of a common culture is correct, this would imply that political borders do not necessarily coincide with cultural and religious frontiers. All the cities mentioned above were situated in the frontier zone between the Roman Empire in the West, and the Parthian Empire in the East. Their political fate, however, was rather diverse. Palmyra was part of the Roman Empire, and never belonged to Parthian territory. ${ }^{5}$

${ }^{1}$ M. Rostovtzeff, 'Dura and the Problem of Parthian Art', Yale Classical Studies 5 (1935), 157-303.

${ }_{2}^{2}$ H.J.W. Drijvers, 'Hatra, Palmyra und Edessa. Die Städte der syrisch-mesopotamischen Wüste in politischer, kulturgeschichtlicher und religionsgeschichtlicher Beleuchtung,' Aufstieg und Niedergang der römischen Welt II.8 (1977), 799-906.

3 T. Kaizer, 'Introduction', in id. (ed.), The Variety of Local Religious Life in the Near East in the Hellenistic and Roman Periods (Leiden 2008), 1-11.

${ }^{4}$ M. Sommer, Roms orientalische Steppengrenze. Palmyra-Edessa-Dura-EuroposHatra. Eine Kulturgeschichte von Pompeius bis Diocletian (Stuttgart 2005).

${ }^{5}$ On Palmyra's political history, see Drijvers 1977, op. cit. (n. 2), 837-862. See Sommer 2005, op. cit. (n. 4), 149-170, for references to more recent studies. 
Dura-Europos ${ }^{6}$ and Edessa ${ }^{7}$ initially fell within the Parthian orbit, but changed hands in 165 during the campaign of Lucius Verus. Hatra only joined Rome in about 225, after the Parthians had been defeated by the Sasanians. ${ }^{8}$ Unlike the other cities then, Hatra was connected to the Parthian Empire for most of its existence.

The view that central political powers had little influence on the culture of their subjects is at odds with recent studies on Romanisation that emphasise the role of indigenous elite groups in the process of Romanisation. This new approach resolves around the idea that the coming of Rome resulted, consciously or unconsciously, in a realignment of social relations. Roman culture is thought to have played an important part within this redirection. In order to establish and confirm their elevated social position, elite groups aligned their interests with those of Rome and forged a connection with the Roman rulers to become more like them. ${ }^{9}$ One way of doing this was by adopting Roman cultural elements or incorporating Roman cultural elements into one's own culture. ${ }^{10}$ Notably with respect to civic or public religion in the Roman Empire, it is frequently stressed that politics and religion were in fact two sides of the same coin. ${ }^{11}$

Recent studies of various aspects of Palmyrene culture stress the impact of Roman rule on the local elite of Palmyra. Roman influences to a large extent determined Palmyra's public and religious architec-

${ }^{6}$ See L. Dirven, The Palmyrenes of Dura-Europos. A Study of Religious Interaction in Roman Syria (Leiden 1999), 3-17, for a short introduction to Dura's history and references for further reading.

7 On the history of Edessa, see now S.K. Ross, Roman Edessa. Politics and Culture in the Eastern Fringes of the Roman Empire, 114-242 CE (London-New York 2001).

${ }^{8}$ On Hatra's political fate, see St. R. Hauser, 'Hatra und das Königreich der Araber', in J. Wiesehöfer (ed.), Das Partherreich und seine Zeugnisse (Stuttgart 1998), 515-519.

9 M. Millett, The Romanisation of Britain. An Essay in Archaeological Interpretation (Cambridge 1990); T. Derks, Gods, Temples and Ritual Practices. The Transformation of Religious Ideas and Values in Roman Gaul (Amsterdam 1998), 35; G. Woolf, Becoming Roman. The Origin of Provincial Civilization in Gaul (Cambridge 1998), 4-7.

10 The idea that foreign Roman elements were not necessarily blended into the indigenous culture to merge into a new, typical local culture, was recently advocated by A. Wallace-Hadrill, Rome's Cultural Revolution (Cambridge 2008), 13-14, who points out that elements from different cultures can survive side by side. Interestingly, Wallace-Hadrill's plea for cultural bilingualism was inspired by Fergus Millar's characterisation of culture in Syrian cities such as Palmyra in The Roman Near East, 31 BC-AD 337 (CambridgeMassachusetts-London 1993).

${ }^{11}$ R. Gordon, 'The real and the imaginary. Production and religion in the GraecoRoman world', Art History 2 (1979), 5-34; M. Beard-J. North-S. Price, Religions of Rome, Vol. I (Cambridge 1998), throughout. 
ture, and inspired its honorific sculptures, funerary portraits and other funerary monuments such as sarcophagi and mausoleums. ${ }^{12}$ Surprisingly, this redirection of research has not resulted in a re-evaluation of the cultural remains of Hatra and the relationship between Hatra and Palmyra. If Palmyra's elite assimilated themselves to Rome, one might expect the rulers of Hatra to look to their political overlords, the Parthian kings of kings. Unless, of course, one assumes that the Parthian Empire was politically too weak to exert any cultural influence on its subjected peoples. ${ }^{13}$ This notion is indeed widespread among ancient historians.

In an earlier study, I have challenged the idea that the material culture of all the cities in the Syrian-Mesopotamian desert was fundamentally the same. ${ }^{14}$ In the present article, I shall also dispute the idea that the religious worlds of these cities were more or less identical. To this end I compare material from two cities on either end of the scale: Roman Palmyra and Parthian Hatra. My evaluation is based mainly on the archaeological remains from the two cities that date from the first three centuries of the Common Era. As is well known there are scarcely any literary sources about religion in the two cities.

Before I proceed with a discussion of the two cities, it is necessary to make two methodological remarks. First, in highlighting the cultural and religious differences between cities in the Syrian Mesopotamian desert

${ }^{12}$ K. Parlasca, 'Das Verhältnis der palmyrenischen Grabplastik zur römischen Porträtkunst', Römische Mitteilungen 29 (1985), 343-356; K. Parlasca, 'Palmyrenische Sarkophage mit Totenmahlreliefs-Forschungsstand und Ikonographische Probleme', Koch (a cura di) Akten des Symposiums "125 Jahe Sakophag-Corpus", Marburg, 4.-7. Oktober 1995 (Mainz 1998), 311-317; G. Schenke, 'Frühe palmyrenische Grabeliefs: Individuelle und kulturelle Identität durch Selbstdarstellung im Sepulkralbereich', in K.S. FreybergerA. Henning-H. Von Hesberg (eds.), Kulturkonflikte im Vorderen Orient (Leidorf 2003), 109-116; J.-B. Yon, 'La romanisation de Palmyre et des villes de l'Euphrate', Annales: Histoires, Sciences Sociales 59 (2004), 313-336.

13 This idea was promoted above all by the Sasanian dynasty that succeeded the house of the Arsacids and claimed to restore a centralized kingdom with a centralized church in Iran. Due to the lack of Parthian sources, it is difficult to weaken this view. However, the fact that this idea was advocated by the successors of the Parthians, who used the argument to legitimate their own power and rule, calls for prudence: A. de Jong, 'Sub Species Maiestatis: Reflections on Sasanian Court Rituals', in M. Stausberg (ed.), Zoroastrian Rituals in Context (Leiden 2004), 2-3.

${ }^{14}$ L. Dirven, 'Aspects of Hatrene Religion. A Note on the Statues of Kings and Nobles from Hatra', in T. Kaizer (ed.), The Variety of Local Religious Life in the Roman Near East (Leiden 2008), 209-246. The figurative remains from cities in the Syrian-Mesopotamian desert will be discussed extensively in my forthcoming study on the sculptures from Hatra. 
I do not argue that there was an impermeable frontier and two utterly distinct cultures. I subscribe to the idea, recently advanced by Benjamin Isaac and others, that the so-called frontier between the Roman and the Parthian Empires is more like a zone than a line. ${ }^{15}$ To a large extent, it was an open frontier, through which people and goods could move easily from one region to the other. There is unambiguous proof of this effect. People from Palmyra are attested in Hatra in Temple XIII. ${ }^{16}$ A substantial Palmyrene community lived in Dura-Europos from at least $33 \mathrm{BC}$ onwards until the fall of the city in $256 \mathrm{AD} \cdot{ }^{17} \mathrm{~A}$ dedication to the city god of Hatra in the Hatrene script that was found in Dura-Europos suggests people from Hatra also frequented Dura. ${ }^{18}$ The presence of people from Hatra in the middle Euphrates region is substantiated by graffiti inscribed in pottery found in Kifrin. ${ }^{19}$

In any comparison, however, a study of the differences should be as important as a study of the similarities. It is, after all, the differences that call for an explanation, and not the resemblances. Precisely because there was contact between these cities and because they shared a number of cultural elements, variations testify to local characteristics. These local characteristics may in turn be due to a number of factors, such as cultural history as well as political, social and religious circumstances. Since Hatra was the only one of the Syrian-Mesopotamian cities that belonged to the Parthian Empire for the greater part of its history, it is not unreasonable to suppose that its political alliance accounted for at least some of the differences between Hatra and the other cities.

${ }^{15}$ C.R. Wittaker, Frontiers of the Roman Empire: a Social and Economic History (Baltimore 1994); B. Isaac, The Limits of Empire. The Roman Army in the East (Oxford 1990), 139-140; 418-426; N. Pollard, 'Roman Material Culture across Imperial Frontiers? Three Case Studies from Dura-Europos', in S. Colvin (ed.), The Graeco-Roman East: Politics, Culture, Society (Cambridge 2004), 119-144.

${ }^{16}$ In the so-called thirteenth temple in Hatra, a stele was found that was manufactured in Palmyra and has a Palmyrene dedication: W. al-Salihi, 'Palmyrene Sculptures found at Hatra', Iraq 49 (1987), 53-61, pl. XIII; L. Dirven, 'Palmyrenes in Hatra. Evidence for Cultural Relations in the Fertile Crescent', in K. Jukabiak (ed.), Fifty Years of Polish Excavations in Palmyra (forthcoming).

17 The evidence that testifies to the presence of Palmyrenes in Dura-Europos is assembled in Dirven 1999, op. cit. (n. 6).

${ }^{18}$ In the Temple of Atargatis in Dura, a stele was found with a cultic standard in relief, dedicated to Shamash: R. Bertolino, 'Les inscriptions Hatréennes de Doura-Europos: Études Épigraphique', in P. Leriche-M. Gelin (eds.), Dura-Europos. Études IV 1991-1993 (Beyrouth 1997), 199-214.

${ }_{19}$ M. Gawlikowski, 'Bijan in the Euphrates', Sumer 42 (1983), 21. 
Second, it ought to be noted that juxtaposing Palmyra and Hatra is not a fair comparison. A proper comparison requires two equal parties, and this is by no means the case. Whereas we are well informed about culture and religion in Rome and its dissemination in the provinces, information about Parthian culture, material or otherwise, is very limited indeed. ${ }^{20}$ Ctesiphon, the Parthian capital in Mesopotamia, is a great unknown, and the few material finds from the remainder of the Parthian Empire are dated fairly late in the Parthian era and originate mostly from places on the margins of the Parthian Empire.

In the following discussion, I shall start with a brief overview of the political and social history of the two cities. This serves to put the subsequent discussion of the religious situation into perspective, for religion in each city was largely determined by its individual political and social situation. Because of the different character of both cities, their religious worlds differ as well. However, political alliances influenced the religious culture of both cities too. In the concluding paragraph, two instances will be discussed that illustrate this point.

\section{Short Outline of the History of Palmyra and Hatra}

Around the beginning of the Common Era, Palmyra emerged as a major emporium or 'desert port'. The rise of Palmyra as an important caravan city coincides with active Roman involvement in the city. ${ }^{21}$ Although the formal status of Palmyra in the empire is the matter of debate, there can be no doubt that the city was to some extent subject to Rome from the first century onwards, and that this relationship intensified in the two subsequent centuries. ${ }^{22}$ This involvement was further increased when the Roman limes was extended south into Arabia, which was annexed in $106 \mathrm{CE}$. Palmyra may have regained some of its independence after Hadrian visited the city in $129 \mathrm{CE}$, and the city was renamed Hadriana Tadmor. It became a colony under Septimius or Caracalla. After the famous queen Zenobia commanded Palmyra's revolt against Rome's

${ }^{20}$ For an overview of material remains of Parthian culture and references for further reading, see S.B. Downey, 'Art in Iran iv. Parthian art', Encyclopedia Iranica 2, Fascicle 6 (1986), 580-585.

${ }^{21}$ Pliny the elder wrote of Palmyra as having a quasi independent status between the two great empires Parthia and Rome, but this is certainly anachronistic for Pliny's time: Hist.Nat. 5.88.

${ }^{22}$ Pliny, Hist.Nat. 5.88, note 5. 
hegemony in the East, Aurelian conquered the city in CE 270. After its defeat, the city quickly lost its importance and was turned into a military base on the Strata Diocletiana.

The Palmyrenes very successfully established themselves as middlemen, regulating the trade between the Parthian Empire in the East and the Roman Empire in the West. Palmyra controlled the desert between Palmyra and the Euphrates by means of military force and diplomacy, thereby making caravan trade possible. In addition, the Palmyrenes possessed trading colonies in Parthian cities. ${ }^{23}$ In this respect they did something the Romans could not do for themselves. And they did it so well that they acquired immense riches in the process. Thanks to this wealth, Palmyra developed into a splendid and monumental city during the second century CE.

Our main sources of information on the social organisation of Palmyra are the inscriptions that have been found in the oasis in great quantity. In these inscriptions, kinship terminology is used to denote physical and social relations. In ascending order of inclusion, the inscriptions mention the individual, the family, a group of families or clan, and the tribe. ${ }^{24}$ Initially, families and clans appear to be the principal form of organisation in Palmyra. In due time, we see this structure adapting to that of the Graeco-Roman city. Hence during the reign of Nero the city was artificially split up into four quarters: a well known feature of GraecoRoman cities throughout the empire. ${ }^{25}$ These quarters were administered by four tribes, the representatives of which constituted the boule of the city that is first attested in an inscription dated to $74 \mathrm{CE} .{ }^{26}$ In this way, Roman engagement in Palmyra's municipal affairs certainly contributed to the diminishing importance of traditional social structures and the increasing importance of a civic identity.

Virtually all remains from Hatra, located in the eastern Jazirah about 80 kilometres south-west of present-day Mosul, date from the period between the end of the first and the middle of the third century of the

23 On Palmyrene trade, see G.C. Young, Rome's Eastern Trade. International Commerce and Imperial Policy, 31 BC-AD 305 (London-New York 2001), 136-186.

24 On the role of Palmyrene inscriptions in the reconstruction of family relations, see J.-B. Yon, Les notables de Palmyre (Beyrouth 2002), 57-97.

25 D. Schlumberger, 'Les quatre tribus de Palmyra', Syria 48 (1971), 121-133; Recently, T. Kaizer, The Religious Life of Palmyra (Stuttgart 2002), 43-55.

26 The boule is first mentioned in an inscription dated to 74 CE: J. Cantineau, 'Tadmorea', Syria 14 (1933), 174-176, no. 2 B. 
Common Era. ${ }^{27}$ Apart from the last decennia of its existence, the city was in some way subject to the Parthian king of kings. The official status of the city within the Parthian empire is, however, by no means clear. The oldest Hatrene inscriptions refer to the Hatrene rulers as 'lords', whereas from 176/7 onwards, inscriptions call them 'kings'. According to the very plausible interpretation of Stefan Hauser, this shift reflects the increased significance of Hatra within the Parthian Empire. In the year $165 \mathrm{CE}$, the province of Oshroene fell into Roman hands, meaning that Hatra's territory became the frontier zone of the Parthian Empire. ${ }^{28}$ As a consequence of its elevated strategic position, Hatra became a vassal kingdom of the Parthian Empire.

Hatra was of great strategic importance and difficult to defeat, as is clear from the keen interest that both the Romans and Sasanians took in the city. Roman historians tell us that the troops of Trajan and Septimius Severus attempted to conquer the city in vain on three occasions. ${ }^{29}$ In turn, the first Sasanian ruler Ardashir unsuccessfully tried to take the city around 228, before his successor Shapur finally succeeded in $240 .{ }^{30}$ The strategic importance of the city relates to the close relationship between the people who had settled in the city and the people in its territory who adhered to a nomadic way of life. Inscriptions refer to Hatrene rulers as "king of Arab", which suggests that Hatra's territory was known as "Arab", and that its population was called "Arabs". ${ }^{31}$ Several inscriptions from the city show that nomadic and sedentary members of the same

${ }^{27}$ For a brief sketch of Hatra's history, see Drijvers 1977, op. cit. (n. 2), 803-837; Hauser 1998, op.cit. (n. 8), 493-528; M. Sommer, Hatra. Geschichte und Kultur einer Karawanenstadt im römisch-parthischen Mesopotamien (Mainz am Rhein 2003), 19-46; Sommer 2005, op. cit. (n. 4), 355-390.

${ }^{28}$ Hauser 1998, op. cit. (n. 8), 502. Followed by Sommer 2003, op. cit (n. 27), 385 and Sommer 2005, op. cit. (n. 4), 382. For the complicated relationship between Oshroene and Rome during these years, see Ross 2001, op. cit. (n. 7), 29-45.

${ }^{29}$ Trajan's failure in CE 117 (Cassius Dio 68.31) was followed by two attempts by Septimius Severus, in 197 and 199 AD (Cassius Dio 75.1.1-3; 76.9.5-76.12; Herdodian $3.1 ; 3.9)$.

${ }^{30}$ Cassius Dio 80.3.2. Ardashir succeeded in taking Hatra in 240 CE. According to Ammianus Marcellinus 25.8.5, the city was deserted when Jovian and his troops passed the city with the dead body of Julian in $363 \mathrm{CE}$. Literary sources praise the wealth of this city. For an overview of the written sources pertaining to Hatra, see J. Tubach, Im Schatten des Sonnengottes. Der Sonnenkult in Edessa, Harrān und Hatrā am Vorabend der christlichen Mission (Wiesbaden 1986), 228-235.

${ }^{31}$ K. Dijkstra, 'State and steppe. The socio-political implications of Hatra inscription no. 79', Journal of Semitic Studies 35 (1990), 96; St. R. Hauser, 'Ecological limits and political frontiers: The "Kingdom of the Arabs" in the eastern Jazirah in the Arsacid period, in L. Milano-S. De Martino (eds.), Landscapes. Territories, frontiers and horizons in the 
kinship group assembled in sanctuaries in the city. ${ }^{32}$ The Hatrene rulers controlled the nomads that roamed the city's territory, and, through them, the entire region; thus, in order to control the region, the Parthian kings allied themselves with the Hatrene rulers.

\section{The Religious Environments of Palmyra and Hatra}

Like the culture of the two cities, the cults of Palmyra and Hatra have also frequently been lumped together. ${ }^{33}$ It is true that religion in both cities was preponderantly Semitic, with notable Babylonian and Arab influences. $^{34}$ That is, however, as far as the similarities go. Apart from a few names of deities, the religious organisation in the cities was very different. In my view, this distinction is largely due to the different character of the two cities: Palmyra was primarily a caravan city, whereas Hatra was a strategic stronghold that also functioned as a holy city. In addition, however, it can be shown that at least some of the differences were due to their political affiliations. I shall start with a general description and subsequently turn to a discussion of the possible political influences on the religious life of the cities.

Religion in Palmyra mirrors the town's social organization and follows the same development. ${ }^{35}$ The varied origins of Palmyra's inhabitants are reflected in great religious diversity. The divine world of Palmyra comprised at least sixty deities, originating from a variety of traditions. Most of these gods functioned as the ancestral deities of individuals and families. In turn, the families assembled to worship their deities in clan sanctuaries that were headed by one of the family gods. When Palmyra developed into a city in the first century AD, several of these tribal sanctuaries came to function as the sanctuary of a city quarter. In turn, the divine and human representatives of the most important temples assembled in the city temple, the temple of Bel. As far as we

ancient Near East. Papers presented to the XLIV Rencontre Assyriologique Internationale Venezia 7-11 July 1997, II: Geography and cultural landscapes (Padova 2000) (History of the ancient Near East. Monographs, 3.2), 191.

${ }^{32}$ Notably $\mathrm{H}_{79}$ and $\mathrm{H}_{336}$.

${ }^{33}$ H.J.W. Drijvers, 'Mithra at Hatra? Some Remarks on the Problem of Irano-Mesopotamian Syncretism' Acta Iranica IV, Études Mithriaques (1978), 167.

${ }^{34}$ J. Caquot, 'Nouvelles inscriptions Araméennes de Hatra I', Syria 29 (1952), 118. Followed by J. Greenfield, 'Nergal dhspt', Acta Iranica 12 (1988), 135-136.

${ }_{35}$ M. Gawlikowski, 'Les dieux de Palmyre', ANRW II 18.4 (1990), 2652-2653. Recently Dirven 1999, op. cit (n. 6), 97-98 and Kaizer 2002, op. cit. (n. 25), 239. 
can tell, the gods did not lose their original character in this process. Although they acquired a new meaning when incorporated into a new constellation, their original character and cult remained unaltered. ${ }^{36}$ During the first three centuries of the Common Era, these three levels of religious organisation changed according to social developments in the oasis. In due time, tribal structures became less important, whereas the civic, supra-tribal character became increasingly prominent. ${ }^{37}$

The first thing that strikes one in comparing the religious world of Hatra with that of Palmyra, is how few deities were worshipped in Hatra. ${ }^{38}$ Instead of sixty names, the inscriptions of Hatra yield only about seventeen divine names. ${ }^{39}$ Furthermore, it is clear that many of these names refer to various manifestations of the same god. Hence Maren is also called Shamash and Nasr, Marten is also known as Allat or Iššarbel, and Barmaren is possibly another name for the god Nergal. ${ }^{40}$ The figure of Heracles, who is exceedingly popular in the city, is known as Nergal, but also appears as the Gad or protective deity of a number of groups or places. ${ }^{41}$ Together, these four deities figure in eighty percent of the inscriptions.

${ }^{36}$ The most obvious examples are the gods Iarhibol and Aglibol, who are both members of the triad of Bel in his temple, but are still worshipped in their older manifestations in sanctuaries in the city: Dirven 1999, op. cit. (n. 6), 47-63.

37 Dirven 1999, op. cit. (n. 6), 66.

${ }^{38}$ For an overview of religion in Hatra and references for further reading, see T. Kaizer, 'Some Remarks on the Religious Life of Hatra', Topoi 10 (2000), 229-252.

${ }^{39}$ For a list of the divine names that are attested in inscriptions from Hatra, see the index in B. Aggoula, Inventaire des inscriptions Hatréennes (Paris 1991), 195. The following deities are attested in the inscriptions (in alphabetical order): Allat, Atarata (Atargatis), Bel (?), Baalshamin, Barmaren, Gad, Iššarbel, Zaqyqu, Maren, Marten, Nanaia, Nergal, Nabu; Nasra, Shahiru, Shahru, Shamash.

40 On the identity of Shamash-Maren-Nasr, see Tubach 1986, op. cit. (n. 30), 261-270. On Allat-Ǐšarbel-Marten, see J.T. Milik, Dédicaces faites par des dieux (Palmyre, Hatra, Tyr) et des thaises sémitiques à lépoque romaine (Paris 1972), 338; J. Hoftijzer, Religio Aramaica (Leiden 1968), 52 with note 2, concludes from H81, a graffito in which Nergal takes the place normally taken by Barmaren, that Barmaren and Nergal were in fact the same god. Although this pushes the evidence too far, the two were undoubtedly closely associated. On the cult of Barmaren in Hatra and its relationship with the cult of Nergal, see G. Theuer, Der Mondgott in den Religionen Syrien-Palaestinas. Unter besonderer berücksichtigung von KTU 1.24 (Göttingen 2000), 390-399.

${ }^{41}$ About a quarter of all divine images from the small shrines represent Heracles (of the 107 statues of divinities that were unearthed in the small shrines, 29 are representations of the Greek god). Furthermore, the cult of Nergal-Heracles is attested in 9 of the 14 small shrines. On the cult of this god in Hatra, see now L. Dirven, 'My Lord with his Dogs. Continuity and Change in the Cult of Nergal in Parthian Mesopotamia' in L. Greisiger, C. Rammelt. J. Tubach (eds.), Edessa in hellenistisch-römischer Zeit. Religion, Kultur und 
The huge temenos in the centre of the city demonstrates the prominence of a small number of deities that were crucial to the religious life of the city as a whole. In this central temple complex Hatra's most important gods were worshipped in various cult buildings. Inscriptions and representations from the great Temenos clearly show that the rulers of Hatra were intimately connected with this set of centralized cults; not only were they the principal commissioners of the cult buildings in the Temenos, but the king of Hatra also figured as the chief priest of Shamash, the principal deity of the city. ${ }^{42}$ In this respect, Hatras main sanctuary differs significantly from the Temple of Bel in Palmyra, which was a communal enterprise financed by many individuals. ${ }^{43}$

The most important deities of the city were not only worshipped in temples inside the central Temenos, but also received a cult in various of the fourteen small shrines located in the living quarters around the great court in the centre. ${ }^{44}$ Several of these small shrines can be ascribed to tribal groups. It follows from inscriptions that were found here, that some members of these groups still adhered to the nomadic way of life. ${ }^{45}$ This suggests the small shrines functioned as a place of assembly for those from outside and from inside Hatra. They gathered here to worship their family gods and to pay their respects to the Gad of the king and the main deities of Hatra that were associated with him. ${ }^{46}$ Hence the function of the small shrines was twofold: on the one hand they affirmed the tribal identity of the people that gathered here; on the other, they formed a bridge between these groups and the central authorities.

Politik zwischen Ost und West. Beiträge des internationalen Edessa-Symposiums in Halle an der Saale, 14.-17. Juli 2005 (Beirut 2009), 47-69.

42 On the intimate relation between rulers and central cult in Hatra, see L. Dirven, 'Hatra: a 'Pre-Islamic Mecca' in the Eastern Jazirah', ARAM 18-19 (2006-2007), 375-377.

${ }^{43}$ M.A.R. Colledge, 'Le temple de Bel à Palmyre. Qui l'a fait et pourquoi?', in Palmyre. Bilan et perspectives. Travaux du Centre de recherche sur le Proche-Orient et la Grèce antiques 3 (Strasbourg 1976), 45-52.

${ }_{44}$ The temples are usually indicated by numerals in the sequence in which they were found. Since it is frequently not known to which god or gods they were dedicated, it is best to follow this custom.

${ }^{45}$ Notably H79. On the relationship between sedentary and nomads in Hatra, see Dijkstra 1990, op. cit. (n. 31), 90-94.

${ }^{46}$ On the tribal character of the cult in the small shrines, see L. Dirven, 'Banquet scenes from Hatra', ARAM 17 (2005), 61-82. The prominent role of the central cults in the small shrines and the role of the king in them have largely been neglected so far and will be discussed in my forthcoming publication on the sculptures from Hatra. 
It is noteworthy that apart from Hatra's main deities, few gods were worshipped in the small shrines. In fact, eight of the fourteen shrines seem to have been dedicated to a god who looks like the Greek god Heracles and who is variously identified as the Gad of a particular family or tribe. In all likelihood, all manifestations of this god were assimilated to Nergal, a deity of Babylonian origin associated with the netherworld. ${ }^{47}$ The prominence of this Heracles figure in the small shrines, and the fact that he seems to embody various tribal deities, suggest that the people who visited the holy city or who settled here assimilated their gods to the deities that were of primary importance in Hatra. This would explain the relatively small number of divine names and divine figures attested in Hatrene inscriptions and sculptures. How exactly this Heracles-figure relates to the gods that were worshipped in the main sanctuaries in the city is not entirely clear. Representations of the god have been found in various temples in the great temenos, which suggests that he received a cult here as well.

This brief overview shows two distinct religious worlds that are illustrative of the way the two cities functioned. In Palmyra, shared interests in economic resources and Roman influence eventually led to the rise of a civic religious identity and a reduction of clan affiliations. The gods of the city that received a cult in the temple of Bel are hardly attested in the tribal sanctuaries in the city. Instead, the main gods from the tribal sanctuaries were assembled in the temple of Bel. Unlike the caravan city Palmyra, Hatra was first and foremost a holy city and a strategic stronghold. As such, it functioned as a political and religious centre for the desert peoples living in and around the city. The tribes gathered in the city centre to pay homage to the main deities of Hatra and to its ruler. In addition, they assembled in their tribal sanctuaries, where tribal affiliations seem to have remained strong throughout. Contrary to Palmyra, the central gods of the city were worshipped in these family temples as well. Furthermore, the tribal deities were frequently adapted to their new habitat and assimilated to Hatra's most important gods.

\section{Religion ANd Politics}

Notwithstanding the distinctly local character of religious life in Palmyra and Hatra, it can be shown that their religion was also influenced by their

47 Dirven 2009, op. cit. (n. 41) on the cult of Heracles-Nergal at Hatra. 
respective political overlords. In both Palmyra and Hatra, these practices were related to the local elite or to local rulers, who used foreign religious elements to confirm their own position.

The sole instance of clear Roman influences in the religion of Palmyra is the imperial cult. Evidence of the cult of the Roman emperors is confined to three, or perhaps four, inscriptions. However, these inscriptions do show beyond doubt that the imperial cult was of civic importance. The office of priest of the imperial cult was fulfilled by the symposiarch and high priest of the god Bel, the most prestigious religious office of the city. ${ }^{48}$ Hence the imperial cult was extremely well integrated into the civic, communal life of Palmyra. As in cities in Asia Minor, the imperial cult was dominated by the local elite. This incorporation is reflected in the iconography of Palmyrene gods, that was influenced by the image of the emperor. Around the middle of the first century, shortly after Palmyra's incorporation into the Roman Empire, a significant change took place in the iconography of Palmyra's most important deities. As in many cities and villages in the region, military deities were extremely popular in Palmyra. ${ }^{49}$ Before the advent of the Romans, the gods were depicted wearing a so-called lamellar-cuirass, of Hellenistic origin. ${ }^{50}$ Around $80 \mathrm{CE}$, however, the most prominent gods of the city such as Iarhibol, Aglibol and Arsu, changed their costume, adopting a Roman muscle cuirass, the cuirass normally worn by the Roman emperor. ${ }^{51}$ It is noteworthy that it is only the city gods of Palmyra that take on this costume; the military deities worshipped in the villages around Palmyra remained clad in their traditional outfit. This suggests that the adoption of the emperor's dress for Palmyra's deities assured these deities a place in the Roman order. That the adoption of the Roman cuirass was indeed related to Roman rule is confirmed by the gods of Parthian Hatra, who were not represented wearing Roman armour. ${ }^{52}$

${ }^{48}$ For an overview of all material that possibly refers to the imperial cult in Palmyra, see Yon 2002, op. cit. (n. 24), 122-123, with note 191.

${ }^{49}$ H. Seyrig, 'Les dieux armés et les arabes en Syrie', Syria 47 (1970), 92.

${ }^{50}$ In many publications, this type of cuirass is referred to as 'strip cuirass'. 'Lamellar cuirass' is, in fact, the proper designation. I thank Andreas Kropp for this information.

${ }^{51}$ On the adoption of the body cuirass by Palmyrene deities and its implications for emperor worship, see L. Dirven, 'The Julius Terentius fresco and the Roman Imperial cult', Mediterraneo Antico 10. 1-2 (2007) [2010], 1-13.

52 Contra Sommer 2005, op. cit. (n. 4), 386, who argues that cuirassed gods are common in the divine iconography of Hatra. In fact, only two representations of cuirassed gods are known to date; the statue of a bearded god flanked by eagles from Temple $\mathrm{V}$ (Drijvers 1977, op. cit. (n. 2), 808) and a relief from the great Temenos (S. Downey, 'A Stele 
In Parthian Hatra, Iranian influences are mainly found in administrative titles and are hardly noticeable in the religious sphere. ${ }^{53}$ The epithet Dahashpata, 'Lord of the Guards', associated with the god Nergal, is one of the few exceptions. ${ }^{54}$ All gods were of Semitic stock and none appears to have been assimilated to an Iranian deity. ${ }^{55}$ However, if my interpretation of one of Hatra's religious buildings is correct, there is one noticeable exception to this rule. Somewhere around 170, Sanatruq, the first king of Hatra, constructed a square building behind the great southern iwan in the central Temenos. From an architectural point of view, this building is an anomaly in Hatra's religious architecture. In view of its obvious similarities to Zoroastrian fire temples dated to the Sasanian period, it was formerly identified as an Iranian fire temple. ${ }^{56}$ However, since Iranian gods do not otherwise feature in Hatrene religion, this hypothesis is now generally rejected. Most scholars hold that the building was dedicated to Shamash. I propose to return to the former interpretation, albeit with a slight alteration. In my view the 'Square Building' housed the dynastic fire of the Hatrene monarchs.

The ascription of the building to Shamash is based on the presence of a bust of a sun god, who is represented in the centre of the lintel of the door that leads into the Square Building. ${ }^{57}$ Since door lintels are not the most obvious place to express theological notions, this argument is rather unconvincing. Doubt is augmented by the fact that no inscription dedicated to Shamash has been found in the Square Building. In fact, divine names hardly figure in inscriptions from this building, nor are many gods represented in the figurative decoration. Instead, numerous

from Hatra', Sumer 30 (1974), 179-182). The gods from Hatra wear Hellenistic lamellar and strip cuirasses, rather than the Roman muscular cuirass.

${ }^{53}$ On Iranian titles in Hatra, see Greenfield 1988, op. cit. (n. 34), 136.

${ }^{54}$ Dirven 2009, op. cit. (n. 41), on the possible Iranian-Semitic syncretism reflected in this name.

${ }_{55}$ Drijvers 1978, op. cit. (n. 33), 151-186.

${ }^{56}$ K. Schippmann, Die iranischen Feuerheiligtümer (Berlin-New York 1971), 489492, quotes previous publications and summarizes the problems. Against the idea that the Square Temple was a fire temple: H. Lenzen, 'Der Altar auf der Westseite des sogenannten Feuerheiligtums in Hatra', in K. Bittel-A. Moortgat (eds.), Vorderasiatische Archaeologie. Festschrift Anton Moortgat (Berlin 1964), 136-138. The identification of the bust of a sun god in the door lintel as Mithra was an important argument in this respect. This identification was convincingly rejected by Drijvers 1978, op. cit. (n. 33), 151-186.

57 W. Andrae, Hatra. I. Teil: Allgemeine Beschreibung der Ruinen. Nach Aufnahmen von Mitgliedern der Assur-Expedition der Deutschen Orient-Gesellschaft (Leipzig 1908), 19-20, fig. 32, Pl. XI; Tubach 1986, op. cit. (n. 30), 410-443; pl. 11a-b. 
life-size statues of royalty were found here.$^{58}$ For this reason, it is unlikely that the place functioned as a shrine for a deity. Doubts are increased still further by the fact that the building in front of the Square Building, known as the South Iwan, was dedicated to Shamash. ${ }^{59}$ This follows from H107, a very important text, which is inscribed on a limestone slab found inside room 4. It refers to the temple (sgyl), which Barmaren built for Shamash, his father. As far as we can tell, the addition of the Square Building did not affect the cult in the South Iwan; at its back wall a cult installation was found that probably served as the base for the cult statue.

The Square Building was probably constructed by Sanatruq I, about fifty years after the great iwans were built. ${ }^{60}$ Sanatruq was the first of the Hatrene rulers who referred to himself as king of Hatra and wore the royal headgear, the tiara. ${ }^{61}$ Both title and crown were probably granted him by the Parthian king of kings, due to the augmented strategic position of the city at the time. ${ }^{62}$ The Square Building strikingly resembles later Sasanian fire temples, that consist of a square chamber topped with a round dome which rests on squinces springing from four corner piers. Sanctuaries with permanent fires are surrounded by roofed ambulatories

${ }^{58}$ All material pertaining to this temple will be published in my forthcoming book on the sculptures from Hatra.

${ }_{59} \mathrm{H} 107$. For the reading and translation, see K. Dijkstra, Life and Loyalty. A Study in the Socio-Religious Culture of Syria and Mesopotamia in the Graeco-Roman Period Based on Epigraphic Evidence (Leiden 1995), 197-198.

${ }^{60}$ A vexed question is who decided to built the Square Building. According to F. Safar and M.A. Mustafa, Hatra. The City of the Sun God (Baghdad 1974) (in Arabic), 334, King Sanatruq I finished the building. Sanatruq I is mentioned in the inscription in the lintel (H199) and in a text inscribed in one of the fragmentary columns that once formed a baldachin. Unfortunately, it can no longer be established whether Sanatruq I started the building or whether he finished a building that was begun by his predecessors. Roberta Venco-Ricciardi dates the foundation of the building to the reign of Nasru, around 130$140 \mathrm{CE}$ (oral communication). However, the style of the lintel that adorns the door that leads into the Square Building substantiates a much later date, in the reign of Sanatruq I (above, note 57). Compared to the other lintels that decorate the doors in the North and South Iwan Complex, the style of this lintel is remarkably un-classical and crude. It is much closer to the architectural decoration in the Temple of Allat, dated to the reign of King Sanatruq (Sommer 2003, op. cit. (n. 27), figs. 37, 55, 69, 70), than to the remainder of the architectural decoration from the great iwans (W. Andrae, Hatra. II. Teil: Einzelbeschreibung der Ruinen. Nach Aufnahmen von Mitgliedern der Assur-Expedition der Deutschen Orient-Gesellschaft (Leipzig 1912), figs. 249-251, pl. XII; Sommer 2003, op. cit. (n. 27), fig. 96).

${ }^{61}$ On the change in Hatra from $m r n$ (lord) to $m l k$ ' (king), see Sommer 2005, op. cit. (n. 4 ), $370-376$.

${ }^{62}$ Above, n. 28. 
which protect the fire burning in the inner chamber. ${ }^{63}$ The fact that the construction of this building of Iranian appearance coincides with the intensification of the relations with Parthia strongly suggests that its function is also related to the Arsacids.

Not much is known about the fire cult during the Parthian Era, as is the case with most things related to the Parthians. In fact, it seems that the temple-cult of fire familiar from later Zoroastrian practice appeared fairly late in Iran, and probably only fully developed in the Sasanian period. The worship of various kinds of sacred fires did exist before this date, however, probably in conjunction with other forms of worship. ${ }^{64}$ One such form of fire worshipping is dynastic fire. Its use and meaning must be pieced together from Iranian sources dated before and after the Parthian era. It may be inferred from an account by Diodorus Siculus that a sacred fire was lit upon the accession of the Persian king and was extinguished at his funeral. ${ }^{65}$ In all likelihood, this custom derived from the well-attested example of a householder's fire that was lit for every man in his own home. ${ }^{66}$ The eternal fire at Asaak in Astauene, where the Parthian king Arsaces I was crowned, may very well have been such a dynastic fire. ${ }^{67}$

By the end of the Parthian period, the sub-kings and great vassals of the Arsacids had established dynastic fires of their own, possibly with the knowledge of the Parthian king of kings. This is known from a text called the "letter of Tansar", Ardashir's high priest. Tansar's letter is written in defence of the founder of the Sasanian dynasty, who was accused by a former Parthian vassal king of having extinguished many dynastic fires of other former Parthian vassal kings. ${ }^{68}$ According to Tansar, these fires had been installed without royal authorisation, so that Ardashir had every

${ }^{63}$ M. Boyce, 'Zoroastrian Temple Cult of Fire', Journal of the American Society 93.5 (1975), 462.

${ }^{64}$ Boyce 1975, op. cit. (n. 63), 462, who argues that the fire cult and the cult of images initially existed side by side.

${ }^{65}$ Alexander ordered all the inhabitants of Asia to ... "extinguish what the Persians call the sacred fire, until the funeral was over. The Persians were accustomed to do this on the death of kings. So the people thought the order was an ill omen, and the deities were foretelling the king's own death". (Diodorus Siculus 17.114.5). Translation A. Kuhrt, Persian Empire Sourcebook: a Corpus of Sources of Achaemenid Period (London-New York 2007), 571.

${ }^{66}$ M. Boyce-F. Grenet, A History of Zoroastrianism. 3. Zoroastrianism under Macedonian and Roman Rule (Leiden 1991), 17.

${ }_{67}$ Mansiones Parthicae, par. 11.

${ }^{68}$ M. Boyce, The Letter of Tansar (Rome 1968), 47 (translation) and 16-17 (notes). 
right to remove them. In fact, however, the vassal kings probably did have royal authorization, but from the wrong royal house. As for the religious meaning of these fires, it seems that they embodied the divine Fortune of the king and provided a divine legitimation of his rule. Undoubtedly, this incited Ardashir to destroy these fires and centralise the cult around his own person and dynasty. ${ }^{69}$

The hypothesis that the Square Building housed the dynastic fire of the Hatrene royal house accords well with the foundation of the building at the time that the Hatrene lords were granted royal status by the Parthian king of kings. This function is confirmed by the large number of royal statues set up in the ambulatory of the Square Building. ${ }^{70}$ The close association between the king and the gods is apparent from $\mathrm{H}_{79}$, found in Temple XI, that speaks of 'the Fortune of the king that is with the gods', a concept that recalls Iranian xwarrah. ${ }^{71}$ The new and elevated position of the Hatrene rulers is not a radical departure from the existing political and religious situation. The Parthian notion was a supplement that was integrated into the existing situation without apparently altering it substantially.

\section{ConCLUSION}

It follows from the above that the religious worlds of Palmyra and Hatra differed substantially. These differences are mainly due to the distinct character of the two cities, which in turn results from their own peculiar economic and social histories. Politics did not have a profound effect here. The elites of both cities did, however, adopt religious elements from their respective political overlords that confirmed their elevated position. Although the political frontier between the Roman and Parthian Empire by no means gave rise to two utterly different religious worlds, there

69 Early Sasanian coins have the image of the dynastic fire of the reigning monarch on their reverse, identifying it as such (e.g. "Fire of Ardashir"): M. Alram-R. Gyselen, Sylloge Nummorum Sasanidarum I. Ardashir I.-Shapur I. (Wien 2003), 49-59 (P.O. Skaervo).

${ }^{70}$ In total, seven life-size statues of royalty were found here whereas no statues of other people were recovered. Safar-Mustafa 1974, op. cit. (n. 6o), figs 1-4 and 8-10.

${ }^{71}$ Already Dijkstra 1990, op. cit. (n. 31), 89. For the debate on the exact meaning of this notion, see A. de Jong, 'Neither in ideology, nor in art. Reassessing the concept of xwarrah in Sasanian Iran' (forthcoming). I am grateful to Albert de Jong for sending me this unpublished manuscript. 
RELIGIOUS FRONTIERS IN THE SYRIAN-MESOPOTAMIAN DESERT 173

is ample proof that political alliances account for at least some of the differences in the religious domains of Palmyra and Hatra.

Amsterdam, January 2010 